\title{
Legitimate and Illegitimate Reading
}

Speculative Fiction Readers' Strategies of Distinction

Lectures légitimes, lectures illégitimes. Se distinguer en lisant des littératures de

l'imaginaire

\section{Élodie Hommel}

Translator. Alba Simaku and Marie-Pierre Pouly

\section{(2) OpenEdition}

\section{Journals}

Electronic version

URL: https://journals.openedition.org/bssg/588

DOI: $10.4000 /$ bssg.588

ISSN: 2490-9424

Publisher

Presses universitaires de Vincennes

\section{Electronic reference}

Élodie Hommel, "Legitimate and Illegitimate Reading", Biens Symboliques / Symbolic Goods [Online], 8 2021, Online since 20 May 2021, connection on 23 July 2021. URL: http://journals.openedition.org/ bssg/588 ; DOI: https://doi.org/10.4000/bssg.588

This text was automatically generated on 23 July 2021.

Biens Symboliques / Symbolic Goods 


\section{Legitimate and Illegitimate Reading}

Speculative Fiction Readers' Strategies of Distinction

Lectures légitimes, lectures illégitimes. Se distinguer en lisant des littératures de l'imaginaire

\section{Élodie Hommel}

Translation : Alba Simaku and Marie-Pierre Pouly

Fig. 1.

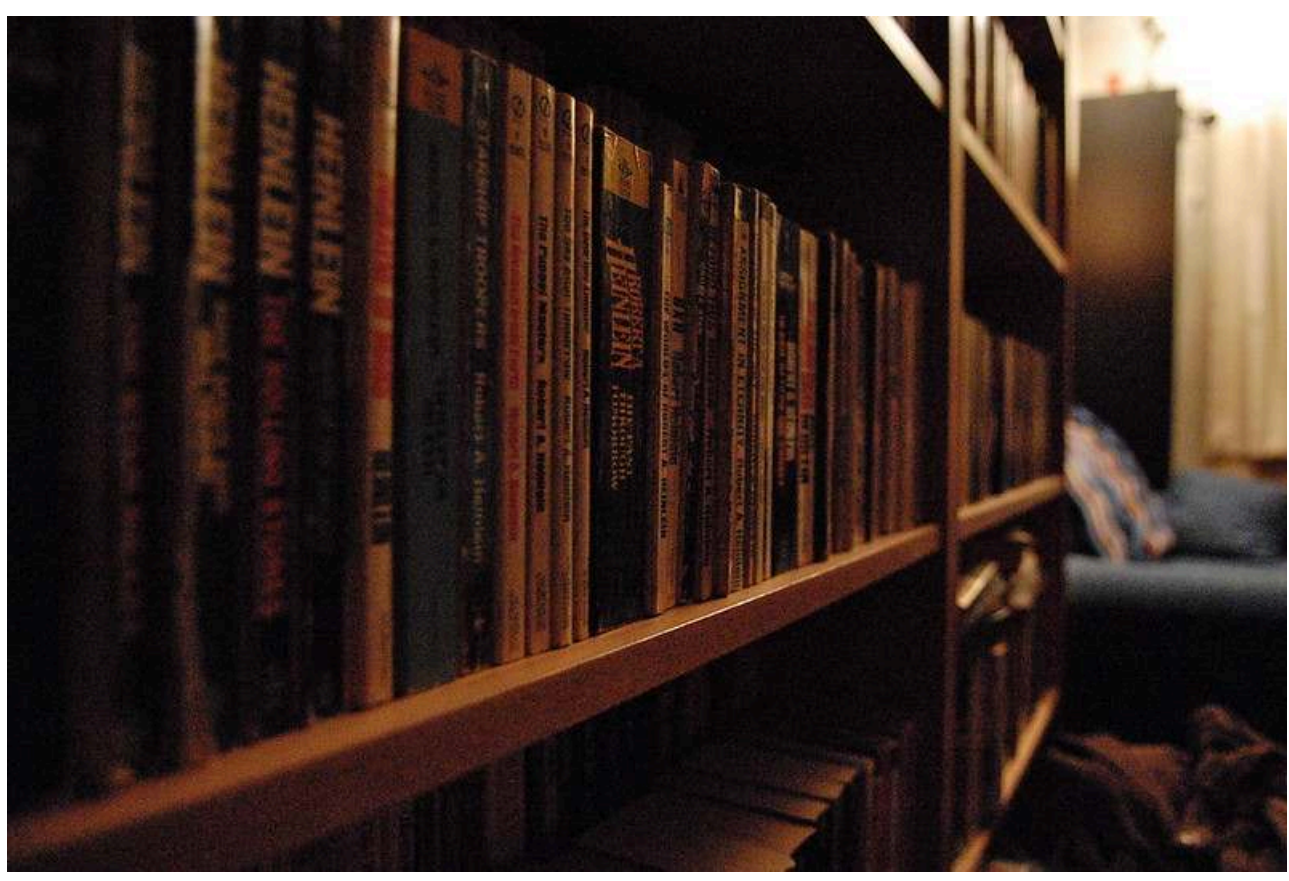

«Old-Time Science Fiction », by Ken Ficara

Source: Flickr

Speculative fiction, comprising both science fiction and fantasy, includes extremely varied productions ranging from "classical" works recognised by dominant cultural 
institutions to mass-printed, commercially successful books. Associated with entertainment and youth culture, the category as a whole suffers from a lack of legitimacy, as confirmed by the exchanges between publishers concerned about the image of the genre. A publisher from Diable Vauvert stated: "We're better off not publishing our authors in a Sci-Fi ${ }^{1}$ collection. It would ghettoise them if we did" (Jakmakjian 2001).

Despite its partly illegitimate nature, as well as the "pop" literature tag that it is often attributed, speculative fiction is far from being rejected by readers with strong cultural capital. It is cited as the most read novel genre by $31 \%$ of novel-reading executives and higher intellectual professions and by $28 \%$ of novel-readers with two or three years of higher education (Donnat 2009). Besides, the sociology of audiences and reception has demonstrated the chancy nature of associating a type of cultural production to a specific audience or reception mode (Charpentier 2006). It is just as possible to read Madame Bovary and be entertained by the sentimental twists of Emma's life, as to carry out a stylistic analysis of Harry Potter. Reading, regardless of genre, is likely to be used legitimately. As well as an ethical-practical resource (Lahire 1993), it thus becomes a social resource: to call oneself a reader constitutes a kind of cultural salvation (Mauger, Poliak, Pudal 1999). How do readers deal with the ambiguous legitimacy of speculative fiction? How do they transform this type of reading, suspected of illegitimacy, into a cultural and social resource? What distinction strategies do they put in place to legitimise their reading practices?

This article originates from a doctoral thesis in sociology, on science-fiction and fantasy reading. It is based on a qualitative study conducted between 2014 and 2015, which includes observations of events and festivals dedicated to the genre, a study of the contemporary French publishing market in speculative fiction and above all interviews with readers. About forty semi-structured interviews, lasting three hours on average, were conducted with young adults between the ages of twenty and thirty-five. Some read occasionally while others read assiduously; some solely within the genre, others more widely. The approach made sure to include a variety of social profiles, in terms of gender, socio-professional groups, social contexts, places of residence and cultural, scholarly, and academic backgrounds.

Despite the reading habits of the young adults surveyed being at times subjected to legitimacy judgments from their entourage (parents, teachers or peers), these do not necessarily constitute a hindrance to their reading practice. Speculative fiction indeed presents an internal legitimacy hierarchy, which allows for those who master the codes to stand out through their reading choices. Real distinction strategies are thus established amongst readers, particularly those with strong cultural capital, who favour more literary choices, read the text in its original version, and adopt scholarly reading methods.

The partly illegitimate character of speculative fiction also allows for less culturally equipped readers to approach reading via texts that are less "intimidating" than cultural classics. The simple act of reading, regardless of genre, thus becomes distinctive and constitutes a social resource that allows readers to partly circumvent their assigned social status. 


\section{Judgements of Legitimacy: A Hindrance to Reading?}

\subsection{Parental Concern and Cultural Goodwill}

A number of judgements that the surveyed young adult readers generally faced arose during the interviews. Readers recounted critical discourses, often heard during adolescence, but which were still commonly heard at the time of the survey: these judgements portray speculative fiction as childish, not serious enough or disconnected from reality. They come from parents as well as from school institutions or peers, and could constitute hindrances to reading, as is the case for young manga readers who have to deal with real "legitimacy conflicts" (Détrez \& Vanhée 2021). Yet for the young adults surveyed here, the actual influence of vertical prescriptions seemed less prevalent than amongst the teenagers interviewed by Christine Détrez and Olivier Vanhée. Once an adult, the memory of school judgements and parents' opinions tends to exert less pressure, and leaving the family home also allows for readers to escape their parents' scrutiny concerning their reading choices. These legitimist reading critiques were, however, not absent from the participants' past experiences, as evoked by Marc:

“They would have rather I read something else. For me to be more focused, I don't know... less in my dream-world maybe. For me to be more into reading books that would help me with my studies later on, to find a job, to find... anyway, when I was in secondary school, they were really focused on me 'succeeding academically, doing everything to do well in my studies,' [...] They wanted me to study, get a job... make enough money. When I was fourteen, fifteen, I didn't give a damn." Marc, 29 years old, unemployed, secondary school level ${ }^{2}$, father is a railway officer and team leader in the French public railway service; mother has no occupation.

Parental criticism thus highlights the genre's supposedly childish character ("It's for children") or lack of legitimacy ("You should read something else"). In Marc's case, what resembles the cultural goodwill characteristic of the middle class (Bourdieu 1984) transpires as concern about academic success. In this working-class family, the relationship with school and educational morals (Buisson-Fenet \& Landrier 2008) put in place by parents seems to stem from a trust in meritocracy, which would allow for those who try hard to free themselves from their background and gain access to new academic and professional opportunities ${ }^{3}$. Thus, Marc's parents link his academic difficulties to his reading choices, which they see as academically unprofitable.

Cultural goodwill takes a different form, however, amongst parents of another section of the surveyed readers, composed mainly of students with good academic results, whose reading habits have never been challenged but rather encouraged ("As long as I'm reading, they're happy"). Good grades at school - seen as proof of seriousness and ability to conform to academic prescriptions gave these teenagers the freedom of reading whatever they wished in their free time, including less legitimate novels. The mere fact of reading books, which are more culturally legitimate than other cultural objects, probably compensated for the genre's lack of legitimacy.

In our survey, this open parental attitude is found amongst the working class as much as the upper class, although cultural goodwill is usually associated with the middle class for Bourdieu. However, consuming fewer legitimate cultural productions on the condition of nonetheless demonstrating one's ability to uphold more legitimate 
practices rather echoes the cultural eclecticism typical of the upper class (Coulangeon 2004). Reading novels, even when they are judged not serious enough, thus usually remains a legitimate cultural bastion favoured in parental discourse, who concentrate their critiques and concerns on other media, such as video games or role play, linked to the media-centred panic regarding these practices around the turn of the millennium ${ }^{4}$.

"With my mum, yeah, when it came to that... when I told her I was into role playing, she asked me if I was suicidal or something! You know, in rural areas, the stuff that gets repeated over and over in the media, urban legends and all that, so... all role players are suicidal Satan worshippers, everyone knows that! (ironic tone)" Julien, 25 years old, education assistant and freelance journalist, scientific classe préparatoire ${ }^{5}$, master's in history, master's in book publishing, father is a blue-collar worker, mother is looking for work.

\subsection{Scorn from Academic Institutions}

Alongside judgemental parents, many of those surveyed confess having received disapproving looks from their teachers. The readers' enthusiasm for teachers who welcomed their passion for the genre attests to the rarity of such professorial positions:

"I was really happy when, on Monday in an essay class, one of our teachers cited Tolkien in his preface to The Lord of the Rings. Oh, that's so great! That's so great! (laughs)." Marlene, 23 years old, student preparing the grammar agrégation, master's in classics, father is a physiotherapist, mother is head nurse in a nursing home.

The reception of academic works (presentations, master's dissertations or even doctoral thesis) on speculative fiction reveals the varying levels of legitimacy within the genre according to disciplines (Marie-Claire, who went to a business school after a classe préparatoire, refers to a contrast between English literature and French literature classes in that respect), institutions, or research trends. Anaiis was allowed to do a presentation on a fantasy novel during her bachelor's degree in literature, Esther wrote a paper on the modelling of the world in Robin Hobb's work for her master's in geography, Philippe wrote a dissertation in English language and literature studies on Dune and Perrine wrote a dissertation on political systems in science-fiction. Yet, alongside successful experiences of using their reading tastes for academic purposes, Perrine and Esther were also discouraged to pursue their research interest at a doctoral level. Perrine interpreted the refusal she encountered as a consequence of budget restrictions that French universities are submitted to, which discourages financing doctorates outside of supposedly "promising" fields, as defined by the research administration. Esther also explains her experience through factors linked to research politics: with hindsight, she realised that she did not address people within the correct research trend ${ }^{7}$ to get her project validated. If speculative fiction is carving out a space for itself in French academic institutions, as testified by the creation of research laboratories (the Centre d'études et de recherches sur les littératures de l'imaginaire [Centre for Speculative Fiction Studies and Research] at University Paris XII-Créteil, or the Centre de recherches littéraires sur l'imaginaire et la didactique [Centre for Speculative Fiction Research and Didactics] at the University of Artois), scientific journals (Féeries since 2003, Res Futurae since 2012), dedicated seminars or colloquia, this recognition is still far from being widespread. 


\section{A Hierarchy of Legitimacy within the Genre}

While judgements from parents, professors or the media that present speculative fiction as a "minor" genre often apprehend it as a whole, there nonetheless exists a legitimacy hierarchy within the genre. The most commercial stories or those aimed at younger readers are the most criticised.

The designation "speculative fiction" indeed includes an abundant and plural set of productions, from blockbusters to award-winning stories, which are sometimes science fiction, fantasy or somewhere in-between. These different categories are the object of much debate and at times virulent positioning from its promoters - authors, editors and literary critics (Torres 1997). Above all, many fault lines stem from the definition of science fiction, its delimitation and its connection to fantasy.

On the one hand, those who accentuate the word "science" in "science fiction", represented in France by author and critic Gerard Klein, consider that the genre must call upon "hard sciences" and propose rational or realistic explanations to the phenomena it portrays. This "purist" vision of science fiction is more restrictive: it in fact excludes all hybrid stories, those that contain magical elements or stray away from rational logic. Others adopt literary critic and academic Darko Suvin's definition, whereby science fiction is above all a projection into a different space or time, with a literary or philosophical component (Suvin 1977). Realism matters less here, as the point is to portray a representation of humans or our relationship to the Other (aliens, for instance), and the reflection rendered possible by this displacement. This trend is thus open to all sorts of other worlds, whether magical or futuristic projections. It can thus include hybrid stories and even pure fantasy.

Beside these definition stakes, characteristic of speculative fiction, contrasts that are more common to the literary field can be found between the poles of limited circulation and of commercial production ${ }^{8}$ (Bourdieu 1991). The legitimacy hierarchy within the genre thus builds upon genre-specific criteria as well as more general literary criteria. The present-day market for speculative fiction reflects these different rifts, with opposing editorial policies: between legitimist and business logics, and between the integration or exclusion of fantasy, as illustrated by the diagram below ${ }^{9}$. 
Fig. 2.

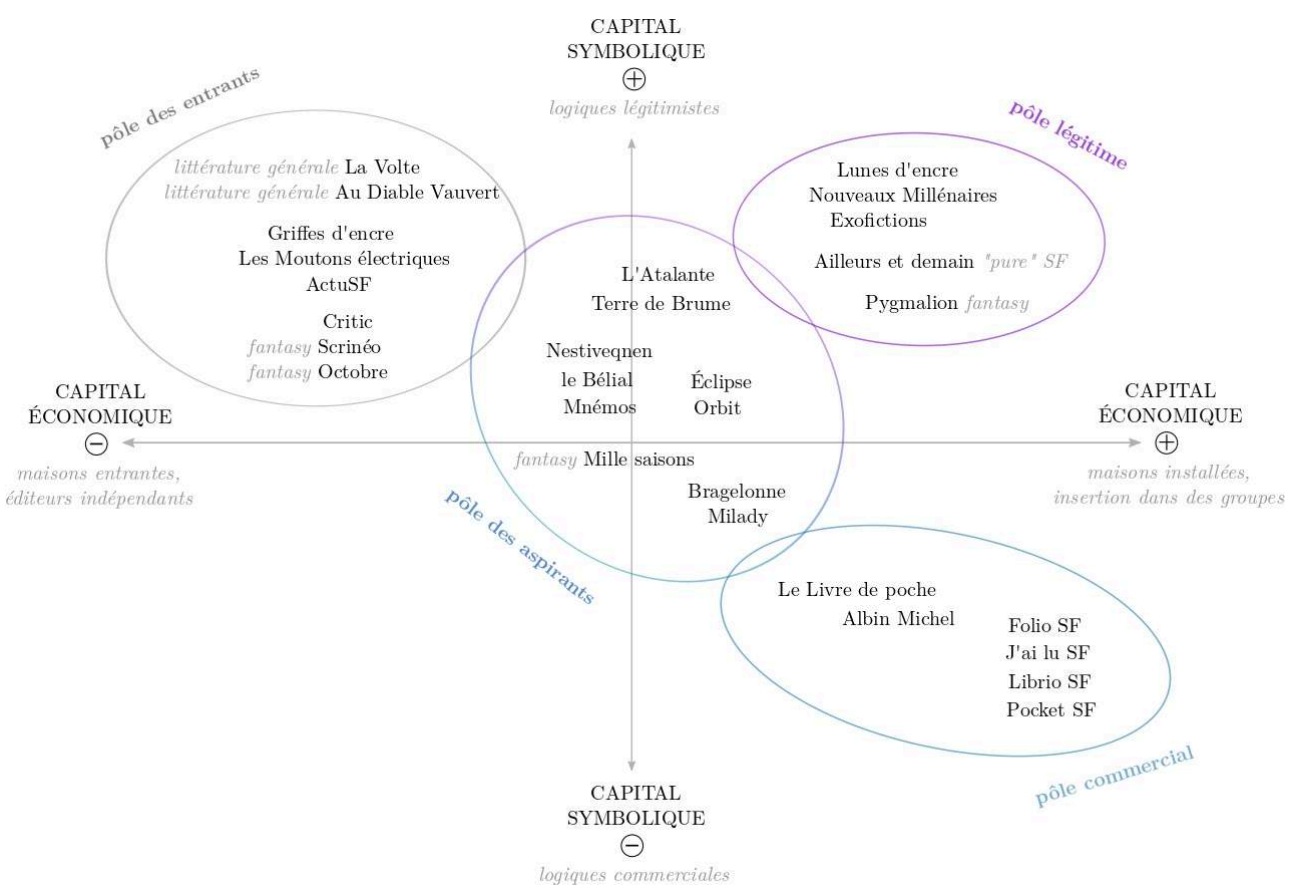

Mapping the contemporary French publishing offer in speculative fiction

Source: Élodie Hommel (2017)

This hierarchy is acknowledged, to varying degrees, and according to different modalities, by the surveyed readers. Readers who have studied scientific disciplines or work in technical or scientific fields are more likely to resort to genre-specific criteria, and specifically evaluate the rational or scientific nature of stories. They pay particular attention to scientific inconsistencies in the novels. Their irritation towards exaggerations, shortcuts or implausible stories are all the stronger when their particular field is involved, as is the case for Laura, a biologist, when it comes to questions of genetics, or Olivier, a physicist, when it comes to the worries generated by particle accelerators. Beyond their expertise, their whole apprehension of fictional worlds is impressed by their scientific approach and vocabulary: they talk about accepting "axioms", imagining their "implications" and of "maintaining consistency".

Readers take literary hierarchy criteria into account depending on the extent to which they have internalised erudite cultural norms. The reading effort constitutes a first classification criterion, between books that are easy or hard to read. Engaging with this criterion is mainly based on the readers' experience: no need to have studied literature to distinguish books that are easy to read from those that are trickier. This is an individual experience: some texts judged as easy by some may seem difficult for others, depending on their reading fluency. But the classification of reading according to difficulty comes up amongst nearly all of the participants, even though the limit between easy and hard reads varies individually, according to academic skills and the intensity of reading practices. "Easy" books are usually associated with young adult literature in readers' discourse, and are considered of inferior quality, compared to "harder" texts that require concentration.

"Some are lighter, I would say, like Harry Potter or Hunger Games, they're nice, magical worlds, but they're easy let's say, whereas 1984, Philip K. Dick or stuff like that, it's much darker, more adult, and it is more complicated, you often have to 
read between the lines to understand what the author is trying to say." Anne, 23 years old, webmaster and community manager, bachelor's in information and communication; father is an engineer and director of an IT school, mother is an unemployment counsellor.

Parallel to the reading difficulty, the "commercial", "pop" or "mainstream" nature of books constitutes another widespread classification criterion. A certain rejection of commercial books, considered as more stereotyped productions, "according to a classical process that consists in construing the disavowal of commercial profit as a proof of quality" (Le Guern 2002: 32), features amongst most of the interviewed young adults. Thus, for Thibault, the success of a saga or a sub-genre necessarily means a loss in quality, as the business logic that aims at monetizing a successful series takes over artistic or literary logics ("If it becomes fashionable, fashionable means marketable, and usually, when it becomes too commercial, well, it'll get a bit distorted along the way"). But this "aesthete" hierarchisation of books, opposing commercial productions to texts with a greater literary quality, as well as the awareness regarding the conditions of book production, which attest to the interiorisation of erudite legitimacy norms, mainly occurs amongst readers with strong cultural capital, whether inherited or acquired.

"There's been a big production and then there still is a big low-cost production, for a readership that reads quickly, like, for pure entertainment, easy reads you might pick up at a train station. So, there's a big production - there are good ones in there, mind you - but a large part of the production was on order, authors who produced books on order, who wrote fast, with simplistic stories that were always the same, most of which are books that have been forgotten, but yeah a large part of Sci-Fi production is both very easy to read, and, well... simply written." Perrine, 31 years old, adult education instructor, master's in political sociology, father is a physics researcher, mother is an employee.

Stephenie Meyer's Twilight series appears as the ultimate foil in these exchanges, combining all of the stigma: it's a story for young people that is easy to read, has been commercially successful and is about sentimental themes. If some readers "confess", as they put it, to having read it, they do not find it any redeeming quality, at least not in the interview setting. On the other side of the legitimacy spectrum, certain books are put forward for their literary qualities, and even elevated to the rank of "classics" in the genre. Literary judgement criteria (style quality, depth of vocabulary or complexity of narrative) are also used by individuals from privileged social backgrounds with a strong cultural capital, such as Mathilde, and particularly by those who have done literary studies and integrated the legitimist hierarchy of cultural goods.

"It's true that in the Sci-Fi and fantasy that I read, there's still this taste, you know, for classical literature and beautiful writing, you see, I think that's why I'm more attached to people like Asimov and K. Dick in Sci-Fi, than to other more modern writings, I think I'm attached to the literary style." Mathilde, 29 years old, master's student in industrial pharmaceutics and in charge of clinical research, midwifery studies, bachelor's in biology; father is a general practitioner, mother is a medical neurologist.

Perrine evokes "novels that are nearly [...] classified as general literature actually, that have changed shelves. Like they have been promoted". She hereby testifies to a mastery of literary norms which place certain speculative fiction books above others, but also to the way in which this hierarchy is articulated with that of literary genres amongst themselves, as well as to the knowledge of the "genre extraction" 
phenomenon of certain books that are then admitted into the ranks of general literature (Klein 1977).

\section{Distinction Strategies}

\section{1. "Fans": a Foil}

Knowledge and mastery of the internal hierarchy within speculative fiction allow readers with cultural capital (specifically academic or inherited) to put real distinction strategies into place (Bourdieu 1984). What's at stake is to set oneself apart from "basic" readers, from "bad readers", and even from a stereotypical idea of "fans", who experience reading via "a passionate, even pathological relationship" (Le Guern, 2002: 24). In the case of speculative fiction, as for other cultural objects perceived as less legitimate, illegitimacy in this passionate relationship to the work is coupled with the work's illegitimacy itself. Furthermore, in a context in which cultural eclecticism can be analysed as a new path to distinction (Coulangeon 2003), the exclusivity of a practice, characteristic of "fans", in other words the lack of interest for other practices, also becomes a source of illegitimacy.

Distancing from the pejorative "fan" figure, and especially from its most devalued avatars (Le Bart 2004: 301-302), by readers in search of distinction, goes through the stigma associated with those attitudes considered least legitimate: collecting derived merchandise, getting books signed, projecting oneself into the imagined world uncritically, dressing up as characters. The less legitimate aspects of the obsession are usually associated with youth, lack of maturity, and even a certain naivety ${ }^{10}$, that of childhood or adolescence. Readers, especially those with cultural capital, thus highlight their distance from younger ones, but also from their own childhood practices, in a distinction of "self from self" (Lahire 2004: 30), which brings them to highlight the more legitimate reading modes that are now their own. Valued fan postures, like the aesthetic approach, creation and especially expertise are thus put forward, in interview situations, but also more generally in their relationship with other readers.

The "fan" tag can be claimed as a form of expertise, like Luc does, but on the condition that one distinguishes it from the "basic" fan posture (that Luc contrasts with "great fans", like himself). The expert is inscribed within an encyclopaedic approach, like Thierry when he claims he is "capable of reading chick-lit" ${ }^{11}$ : Making himself read such less well-known productions thus constitutes part of an expert approach, aiming for an exhaustive knowledge of the genre. Even if adopting a culturally valued attitude means those best placed can turn the stigma around and take on the "fan" tag, for most surveyed readers, the word still carries very negative connotations. They thus express a certain reluctance to use the word when speaking of themselves, preferring less tainted words such as "amateur", "devotee" or "connoisseur". This fan ideal type, supposedly a bad reader, was however not met as such during our survey, in which all readers displayed a minimal reflexive use of their reading ${ }^{12}$.

\subsection{Distinctive Choices and Reading Modes}

First of all, distinction happens when choosing books, the idea being not to read "like everyone else". Readers with a strong cultural capital thus often, like Sebastian, 
showcase the less well-known books they might have read, highlighting their search for originality in their reading choices.

"I find French Sci-Fi really creative! [...] French authors go off the beaten track. Yes, and they try to come out of classical patterns, or when they do use them... because it's true that Sylvie Lainé, in her L'Opéra de Shaya collection, I think, in practically all the short stories, there is a more or less explicit galactic order that's established. But... that's beside the point, really, the point is an individual at a given moment and that I find really interesting." Sébastien, 26 years old, head of public relations, IT $B T S^{13}$, master's in communications and events; father is a computer scientist, mother is a CEO assistant.

Reading books that are famously difficult, inaccessible, long, or that demand a high level of concentration also constitutes a source of pride for those surveyed who managed to finish them. They thus distinguish themselves from the mass of "ordinary" readers in the interview context, but also in more informal contexts, during conversations with friends or family, in which some adopt an attitude of genreexperts ${ }^{14}$. Reading stories in an ancient or foreign language also plays into these distinction phenomena, like literary classe préparatoire students who "allow" themselves to read less legitimate novels as long as they read them in their original version (Maridet 2016: 449-450). Thibault thus refers to the magical medieval short stories that he read in medieval French, while Maxime mentions the arid mathematical language in Asimov's Foundation and Amaury claims having studied The Lord of the Rings in "old English" ${ }^{15}$. The animosity that he expresses towards the original version (and the advice to the surveyor not to read it) is also a way of valorising his own reading of the text, inaccessible to most.

"So, The Lord of the Rings, I studied it in my old English class, my God, it's horrendous, truly horrendous, enough to put you off the book forever (laughs), it's awful. The French version, you see, is more modern, easier to read, it's... definitely don't read the original version." Amaury, 30 years old, unemployed and volunteering as a game store manager, bachelor's in English language, literature and civilisation; father works at a printing press, mother is a receptionist.

On the contrary, books considered as bad by these educated readers are rejected, or even disparaged. Often the young adults in question claim that they are incapable of reading these types of productions, as if the hierarchy of legitimate cultural goods, the "disgust for others' tastes", were incorporated to the point of affecting their reading capacity (conversely, these very same readers do not hesitate to emphasise that they "forced" themselves to read difficult but highly regarded books). The other type of reader one must distinguish oneself from is the reader-consumer, who does not have sufficient reading capacities to separate the wheat from the chaff and is satisfied with productions identified as commercial by more informed readers. This identification derives from the ability to tag books and collections according to their prestige ${ }^{16}$, as well as to the concrete reading experience, which is blocked due to a lack of depth or the repetition of stale, derivative narratives. Insufficient stylistic or narrative quality can thus ruin the pleasure of reading.

“There are books like that, I've bought books in kiosks for two euros a piece, mainly horror heroic fantasy, and uhm... out of ten books, I gave up on eight, I stopped reading them." Megane, 31 years old, art gallery manager, master's in international communication and tourism; father works for the civil service, mother is a nurse. 
Those who nevertheless read these books adopt a critical stance, highlighting their distance from texts that could stigmatise them. Marie-Claire indeed claims to have read Twilight in secret while she was a student in a literary classe préparatoire.

Distinction can also be attained through the exhaustive knowledge of a work, which allows an understanding of its different ramifications, and to distinguish oneself from those who have "only" read the most famous books and thus do not grasp its full significance. This is Thibault's case, who congratulates himself on the heightened understanding he has of The Lord of the Rings thanks to having read Tolkien's Silmarillion $^{17}$, as is Luc's case with the Marvel worlds, which he also discovered through the comics and not only through the film adaptations.

"It's really, really the Genesis. Actually in The Silmarillion, The Lord of the Rings is like five pages, it's not much, so indeed, I don't know, there's kind of an elitist edge to the fact that you've read The Silmarillion, you know ten times more stuff than those who have just read The Lord of the Rings, or who have just seen the films, well they don't know, they don't understand..." Thibault, 32 years old, public relations and marketing director, biology and environment DUT ${ }^{18}$, earth sciences DEUG ${ }^{19}$, business school; father is a chef, mother stays at home.

\section{Reading and Erudite Skills}

Beyond choosing what books to read, ways of reading are also distinctive. One can thus sublimate less legitimate books by apprehending them according to erudite norms, or as Pierre Bourdieu expresses it: "In this case, it is the manner of consuming which creates the object of consumption, and a second-degree delight which transforms the 'vulgar' artifacts abandoned to common consumption, Westerns, strip cartoons, family snapshots, graffiti, into distinguished and distinctive works of culture" (Bourdieu 1984: 282-283). Thus, ways of reading that are considered less legitimate are also rejected by readers with strong cultural capital, who, during interviews, embark on proper literary, stylistic or philosophical analyses of the novels they have read, in a distinction attitude which values an elitist reading mode over "ordinary" reading.

Although pleasure is far from absent from the surveyed readers' discourse, reading for entertainment, "reading for fun" (Mauger, Poliak, Pudal 1999), is most criticised. It's not so much the fact of having fun while reading that is criticised, but rather the exclusive search for pleasure in reading, and immersion in the fictional universe without a critical distance, to the detriment of other reading uses judged more legitimate (didactic, "salvatory" or "aesthete"). If, according to Gérard Mauger, Claude Poliak and Bernard Pudal, "pure" aesthete reading rarely exists as such, one can also wonder about the existence of reading for "pure entertainment", seeing how reading studies show that these different social uses are combined within one sitting, in varying proportions depending on individuals and circumstances. Evoking an aesthete reading mode, while showing off for distinction, is however frequent amongst the surveyed readers.

"There are readers like me, who are namely more into reflection and exchange rather than immersion and... it depends, the genre doesn't really influence the kind of readers, but it also depends, readers might encounter a particular genre and these people are immersed in a world, if it weren't a fantasy world they would relate to reading in the same way with another book so... one mustn't demonize fantasy and Sci-Fi... it's the reading mode that... well you can hear the French teacher speaking (laughs)." Ophélie, 22 years old, French teacher in training, first- 
year master's in French literature, literary classe préparatoire; father is a computer

scientist, mother is a nurse.

Readers thus implement stylistic and cultural skills, acquired within the academic context or autodidactically through intensive reading. In her work on secondary school readers, Fanny Renard chiefly distinguishes three types of "analytical reading": synopsis-reading, stylistic reading and comparative reading (Renard 2011: 100-103), which can be found, in varying proportions, amongst the Sci-Fi and fantasy readers interviewed.

\subsection{Comparing and Contextualising Texts}

All the young adults surveyed play the game of comparative reading, to varying degrees. This goes from comparing a novel and its game or film adaptation, to searching for similarities between read novels (characters, narratives, themes), through extensive comparative analysis between many works and identifying cultural or wider literary references. In his analyses of "media cults", Philippe Le Guern notes that audiences often display a "hyper-erudite discourse on the cult work" (Le Guern 2002: 23). Similarly, readers of speculative fiction use numerous and varied references, from science fiction to fantasy as well as other literary genres.

"John Keats was an English poet, early 19th Century, and, uhm, there's a lot of his world in Hyperion, that's why there's a lot of poetry, a way of seeing the world and considering literature and multiplying literature and poets, that's very interesting." Gauthier, 26 years old, film production and distribution master's student, international cultural exchange master's; father is a history and geography teacher, mother is a school psychologist.

While comparative reading pervades all the interviews, the most in-depth analysis and most abundant references are the mark of readers with the highest cultural capital (coming from families with a high cultural capital, with literature degrees or who are avid readers). The references invoked also vary according to the readers' reading diversity, which is either exclusively dedicated to science fiction and fantasy, or extends to other genres, including classics. For readers with strong literary capital, the approach goes beyond comparison, and rather consists of looking for "influences", for the books that have most impressed writers, in a perspective that is closer to literary analysis, which involves critical identification of sources.

Another "erudite" approach, work contextualisation, is also very present amongst the young adults surveyed. Here again, it takes on different forms according to reading investment and cultural capital. More than half of all surveyed readers claim to research, at least from time to time, writers' biographies or bibliographies. Those less invested are content with reading the bio-bibliographical blurbs included in the novels or their corresponding Wikipedia pages, while others engage in more in-depth research, or even go into detailed biographical reading. The knowledge acquired allows them to replace the read books in their production context (authors' personal situation, historical and cultural context).

For the young adults who have studied literature, reading prefaces becomes "automatic", thus completing this biographical and cultural contextualisation approach. The taste for bibliographical research falls within these same trajectories. Many of the readers surveyed thus had the opportunity, within their academic career 
or in their free time, to read critical analyses of speculative fiction in general or of a specific book.

\subsection{An Uneven Attention to Writing}

Analytical relationships to texts can also go through stylistic reading: through attention to writing and stories' narrative structures, through literary textual analysis, such reading "enables the production of a commentary on text structures, bringing to light its effects on a standard reader and elucidating themes and points of view on the world that the text carries" (Renard 2011: 101). When it comes to speculative fiction, this type of analytical skill can be used, whether in the study of narrative, a story's style or the network of characters.

“So, I didn't know Nancy Kress' style, but I really liked it, actually she has a pretty brutal style, with chapters, I mean it comes across as quite brutal. It feels like it's cut with a knife, nothing is superfluous." Marina, 29 years old, public health librarian, biology bachelor's and library DUT; father is a telecommunication senior technician, mother is a saleswoman.

These literary skills are more present amongst readers who have studied literature and the humanities, or whose families have transmitted strong cultural capital, but they can also be found amongst readers who have developed a certain intimacy with texts and their codes via intense reading practices. Although the vocabulary of literary analysis is less developed amongst the latter, their comments demonstrate a sensitivity to style and proven analytical skill.

Beyond analytical skills, uneven internalising of academic literary hierarchies transpires in the attention to style and in the criteria used to judge works. In our survey, the effects of social backgrounds could be felt, for judgements according to literary criteria are more present amongst individuals from families with high cultural capital, but the type of studies and the intensity of reading practices also played a part. Thus, Nadia, a PhD student in geography, although she comes from a working class family with a low cultural capital, has internalised erudite norms through her extensive higher education ("I would classify literature as writing that should be a bit superior") while Marc, also from a working-class family, who has not studied and reads moderately, pays little attention to writing ("The way he writes, the way it is put... I don't care much about that, as long as I liked it").

Re-reading can play an emotional role amongst surveyed readers, plunging them back into familiar worlds. It can also be carried out from an erudite perspective: it allows for a deepening of analysis, studying the text more thoroughly than on first reading. Amongst the young adults surveyed who sometimes re-read books, many declare rereading books while paying attention to details or further dimensions, or with an approach enriched by the knowledge acquired in the intervening time.

"The Wind on Fire, yes, yes, it really is, well actually the guy who wrote it was a philosophy teacher, so there are loads of philosophical references throughout the story, which I rediscovered later, as I also studied philosophy and all. So yeah, in that case it's even more interesting when re-reading it than it was the first time." Ophélie, 22 years old, French teacher in training, first-year master's in French literature, literary classe préparatoire; father is a computer scientist, mother is a nurse.

Speculative fiction, like other cultural productions whose legitimacy is not guaranteed (Collovald \& Neveu 2004; Détrez \& Vanhée 2021), lends itself to ordinary reading as well 
as to erudite reading, confirming that one cannot simply associate a type of cultural production with a kind of audience and reading. Contextualising their reading, catching on to the network of references, analysing style and narrative, re-reading texts: the surveyed readers implement a whole range of literary skills, more or less developed depending on cultural capital, whether inherited, acquired through study or accumulated via extensive reading.

\section{Reading as a Social and Cultural Resource}

\subsection{Reading to Maintain Social Status}

The desire to distinguish oneself and stand out from the crowd is not the prerogative of readers from families with a high cultural capital or those who have acquired such capital through higher literary education. Reading, whether speculative fiction or other genres, can constitute a cultural resource for young working-class adults, particularly those in unstable professional situations. The simple fact of reading anything thus in itself constitutes a distinction criterion compared to other individuals, whose cultural practices are considered less legitimate. To be able to call oneself a reader, despite the circumstances, is thus in itself a kind of "cultural salvation" (Mauger, Poliak, Pudal 1999).

This is for instance Marc's case. After having given up school before obtaining his $b a c^{20}$, he went through a few precarious contracts as an employee or worker, as well as a few years in the army. At the time of the interview, he was in an extremely unstable situation as he was unemployed and had had to leave his apartment. He was currently living in a "squat" and reading allowed him to escape from his everyday difficulties and distinguish himself from the people he lived with. Keeping up with a cultural activity despite being socially downgraded allowed him to differentiate himself from other "squatters", some of whom had been homeless for years, and to put at bay the possibility of not being able to cope. Continuing to read and looking for work thus became two sides of the same struggle to maintain a dignified social status.

"Squatters, well they're really not people who have that... reading is something that goes over their heads, I mean they have other worries, some of them have lived on the streets for years, some of them, well they're at the end of the rope, they're not at all worrying about being culturally entertained, culture just goes over their head." Marc, 29 years old, unemployed, secondary school level; father is a railway officer and team leader in the French public railway service, mother has no occupation.

The situation is similar for Benjamin, a tram driver: reading allows him to distinguish himself from his colleagues, whose cultural practices are reduced, according to him, to sports and radio. Once again, reading allows him to extract himself from his social context, in this case his professional context, which acts as a foil, and that contrasts with his circle of friends made up of many readers who he shares this passion with.

"Let's say that eighty-five to ninety percent of my colleagues are like, radio, beer, football, so it's not very... [...] Not the same kind of people. I have two or three colleagues who I get along with, who I can talk about it with. For instance, I read on this thing [points to his e-reader] at work, because it fits into my pocket, when they... I can't find two minutes of peace. Oh, what's that, it's a Kindle, what's it for? Well it's to read books with... [...] They're not really a literature audience..." 
Benjamin, 30 years old, tram driver, secondary school level; father is a truck driver,

mother is a foster parent.

In both cases, the desire for distinction amongst young adults in working class environments was nourished by a family environment in which their mothers $\operatorname{read}^{21}$, but also by peers, through social ties to individuals from backgrounds with a stronger access to culture, like Marc's ex-girlfriend, or Benjamin's friends. Like reading crime novels, reading science fiction and fantasy allows them to "thwart statutory attributions" (Collovald \& Neveu 2004: 247), whilst maintaining social dignity through legitimate cultural practices carried out in a precarious situation, or extracting themselves from an environment seen as culturally weak to aspire to a more valued social identity, that of a reader.

\subsection{When Imagination Becomes Cultural Capital}

Speculative fiction, like manga or crime novels, can constitute an entry point into reading, thus enabling readers to accumulate cultural capital. Julien for instance relates how fantasy novels helped the secondary school teenagers with difficulties that he watched over while working as an education assistant to discover reading, to enjoy it, and to use it as a resource when facing daily difficulties.

"One day one of them came to me asking... 'So, I learned to read two years ago, I don't read very well, I'd like to read a book. But I want to read a book like you do.' 'What do you mean, read a book like I do?' 'Well, something good!' 'What do you mean?' 'Well when I see you read... you're concentrated, sometimes, you smile, sometimes you frown, and when you talk about it, you're always... I can tell you liked it and that you're happy you read it; you're having a good time but... I'm so bored in life that I think it would do me good'. When a 19-year-old kid says that, you think wow, what a life he must lead... yeah. And he started to read Neil Gaiman (laughs) well, he had never read in his life so he started with let's say teenage fiction, and he read the rest, then another one started to read... Kids who had nothing to do with speculative fiction or book culture. The other one started to read David Gemmel, he went through it all, another one started to read Eddings and went through it all too, in three months." Julien, 25 years old, education assistant and freelance journalist, scientific classe préparatoire, master's in history, master's in book publishing; father is a blue collar worker, mother is looking for work.

His story evokes an initiation to speculative fiction through imitation, not inculcation, on the student's demand, and not on the adults' initiative. The scene happened in a school setting but sideways - in a study room rather than a classroom, with a supervisor rather than a teacher. Though socially improbable, getting into reading was in this case made possible by the presence of participants, who may have been brought closer by their minimal age gap, and through the observation of an unknown practice. As highlighted by Michèle Petit, "for many teenagers who felt unauthorised to venture into reading literary works, due to their social background, one or many encounters with a supervisor - or a librarian - were crucial. These are not necessarily regular, longterm relationships, since a conversation, albeit elusive, can sometimes alter one's fate" (Petit 2002: 167).

Furthermore, for individuals who already read, speculative fiction can help to tame facets of culture deemed intimidating. Many people surveyed thus confirm having dared to tackle "classics" via science fiction or fantasy. Classic literature, assigned in school, is perceived boring or difficult, definitely "not for them", and is thus approached sideways, through certain specific books that pertain to speculative fiction, 
in which readers find what they like in the genre, while being confronted with another cultural world. This is Céline's case, an avid fantasy reader, from a privileged background (father is a doctor, mother a pharmacist), with regular reading practices, but in which "legitimate" culture is absent. In this scientific family, the mother mainly reads science fiction and crime novels, the brother reads fantasy, and only the younger sister (who studies psychology at university) reads "biographies". Céline describes the unexpected discovery of a science-fiction-like passage in Umberto Eco's How to Travel with a Salmon, an author that she associates with legitimate literature and she would otherwise never have dared to tackle ("Umberto Eco is the one who wrote Foucault's Pendulum, a first-class writer. I don't try that kind of stuff").

The same goes for Olivier, from a more working-class family (father is a chief mechanic, mother is an assistant nurse), who has studied science, and has managed to "reconcile with classical literature" via science fiction, through Cyrano de Bergerac's Comical History of the States and Empires of the Moon.

"I'm not at all into classical literature, I can't read it. [...] I must have been reading on the internet, maybe a forum or a Wikipedia page about science fiction, where someone was saying that that was one of the first ever science fiction books, and I thought 'Ah that's great, I want to read it'... [...] That's it, that way I could say that I read classical literature. And I ended up reading both, because in the first one he goes to the moon, and in the second he goes to the sun. So, I read both of them. It ended up kind of reconciling me with classical literature." olivier, 26 years old, student preparing the physics and chemistry agrégation, $\mathrm{PhD}$ in astrophysics; father is a chief mechanic, mother is an assistant nurse.

\section{Conclusion}

Despite the lack of legitimacy from which speculative fiction generally suffers, it can be subject to erudite reading modes and legitimate reception modes, and can thus constitute a cultural resource. Various distinction strategies are thus put into place by its readers. They are supported by the differentiation and hierarchisation of ways of reading, as well as of the choice of books read. Furthermore, speculative fiction shows that distinction phenomena are not the prerogative of the upper classes. In this survey, Bourdieu's distinction principle is not disqualified by the rise of omnivorism (Peterson 2004). But far from being only a way in which upper classes contrast with middle classes and middle classes with working classes, it is also found in individuals whose heritage or educational background is less privileged. Studies on middle class and working-class lifestyles and cultural practices constantly point to their heterogeneity (Bernard 2013; Cartier, Coutant, Siblot, Masclet 2008; Mauger 2013). Similarly, reading speculative fiction highlights the possibility of "micro-distinctions", even amongst individuals with less cultural capital, who find symbolic resources in their reading practices, thus illustrating the persistence of distinction logics and cultural legitimacy hierarchies, even within eclectic cultural worlds. 


\section{BIBLIOGRAPHY}

BERNARD Lise (2013). “Réflexions sur la 'petite bourgeoisie nouvelle' dans les années 2000”. In COULANGEON Philippe \& DUVAL Julien (eds.). Trente ans après "La Distinction" de Pierre Bourdieu. Paris, La Découverte: 266-277.

BOURDIEU Pierre (1984) [1979]. Distinction: A Social Critique of the Judgement of Taste. English translation by Richard Nice. Cambridge, Harvard University Press.

BOURDIEU Pierre (1991). “Le Champ littéraire.” Actes de la recherche en sciences sociales, 89: 3-46. BUISSON-FENET Hélène \& LANDRIER Séverine (2008). "Être ou pas ? Discrimination positive et révélation du rapport au savoir. Le cas d'une 'prépa ZEP' de province." Éducation et sociétés, 21: 67-80.

CARTIER Marie, COUTANT Isabelle, SIBLOT Yasmine, MASCLET Olivier (2008). La France des "petitsmoyens." Enquête sur la banlieue pavillonnaire. Paris, La Découverte.

CHARPENTIER Isabelle (2006). "Pour une sociologie de la réception et des publics.” In CHARPENTIER Isabelle (ed.). Comment sont reçues les oeuvres? Actualités des recherches en sociologie de la réception. Paris, Créaphis: 5-22.

CHARTIER Roger (1985). Pratiques de la lecture. Marseille, Payot \& Rivages.

COLLOVALD Annie \& NEVEU Éric (2004). Lire le noir. Enquête sur les lecteurs de récits policiers. Paris, Éditions de la BPI-Centre Pompidou.

COULANGEON Philippe (2003). "La Stratification sociale des goûts musicaux. Le modèle de la légitimité culturelle en question." Revue française de sociologie, 44(1): 3-33.

COULANGEON Philippe (2004). “Classes sociales, pratiques culturelles et styles de vie. Le modèle de la distinction est-il (vraiment) obsolète?" Sociologie et sociétés, 36: 59-85.

DÉTREZ Christine \& VANHÉE Olivier (2021) [2012]. Mangaddicts. Leyde, Brill (In press). DONNAT Olivier (2009). Les Pratiques culturelles des Français à l'ère numérique. Paris, La Découverte. GLEVAREC Hervé \& PINET Michel (2009). “La 'tablature' des goûts musicaux. Un modèle de structuration des préférences et des jugements." Revue française de sociologie, 50(3): 599-640. HOMMEL Elodie (2017). Lectures de science-fiction et fantasy. Enquête sociologique sur les réceptions et appropriations des littératures de l'imaginaire. $\mathrm{PhD}$ dissertation, Sociology. Lyon, Université de Lyon. JAKMAKEJIAN Aurélia (2001). “Science-fiction: la ruée vers la fantasy.” Livres Hebdo, 427: 65-70. KLEIN Gérard (1977). “Le Procès en dissolution de la science-fiction, intenté par les agents de la culture dominante." Europe, 580-581.

LAHIRE Bernard (1993). La Raison des plus faibles. Rapport au travail, écritures domestiques et lectures en milieux populaires. Lille, Presses universitaires de Lille.

LAHIRE Bernard (2004). La Culture des individus. Dissonances culturelles et distinction de soi. Paris, La Découverte.

LE BART Christian (2004). "Stratégies identitaires de fans." Revue française de sociologie, 45: 283-306. LE GUERN Philippe (2002). Les Cultes médiatiques. Culture fan et œuvres cultes. Rennes, Presses universitaires de Rennes. 
MARIDET Morgane (2016). La Khâgne, un nouveau chapitre. Élaborations et reconstructions du rapport à la lecture des étudiants en classe préparatoire littéraire. $\mathrm{PhD}$ dissertation, Sociology. Paris, Université Sorbonne Nouvelle.

MAUGER Gérard, POLIAK Claude, PUDAL Bernard (1999). Histoires de lecteurs. Paris, Nathan.

MAUGER Gérard (2013). "Bourdieu et les classes populaires. L'ambivalence des cultures dominées." In COULANGEON Philippe \& DUVAL Julien (eds.). Trente ans après "La Distinction" de Pierre Bourdieu. Paris, La Découverte: 243-254.

PETERSON Richard (2004). "Le Passage à des goûts omnivores. Notions, faits, perspectives." Traduit de l'anglais par Suzanne Mineau. Sociologie et sociétés, 36(1): 145-164.

PETIT Michèle (2002). Éloge de la lecture. La construction de soi. Paris, Belin.

RENARD Fanny (2011). Les Lycéens et la lecture. Entre habitudes et sollicitations. Rennes, Presses universitaires de Rennes.

SUVIN Darko (1977). Pour une poétique de la science-fiction. Études en théorie et en histoire d'un genre littéraire. Québec, Presses de l'université du Québec.

TORRES Anita (1997). La Science-fiction française. Auteurs et amateurs d'un genre littéraire. Paris, L'Harmattan.

\section{NOTES}

1. The use of the "Sci-Fi" (Science Fiction) abbreviation constitutes a marker of familiarity with the genre, perhaps even of bonding with the interviewer. It is therefore taken up as such in quotations when thus used by interviewees.

2. The term "secondary school level" applies to individuals who have stopped their schooling before passing their end-of-secondary-school exams.

3. At the time of the interview, Marc seemed to be in a conflictual situation with his family. He did not want to ask them for support and avoided talking about them. We thus do not dispose of the necessary elements to further support this hypothesis.

4. "The recent debates about television programmes hark back to the release of the first edition of the reality show game 'Loft Story', around the year 2000; from that date on, discourse about the effects of violent images on children and adolescents, and about the dangers of addiction have shifted to video games and the internet." (Donnat 2009: 73)

5. The classes préparatoires are selective higher education classes that prepare students in France for the entrance exams of the Grandes Écoles, which are prestigious public higher education institutions.

6. The Agrégation is a competitive entrance exam for secondary school teachers in France.

7. "It would have worked in the field of space representation, I moved in the circles of quantitative geography [...] so I wasn't in the right geography field".

8. The opposition between limited and commercial production also partly intersects with definition contrasts, since the defenders of "projection" science fiction also defend its literary qualities.

9. This graphic representation is based on the analytical model used by Annie Collovald and Erik Neveu (Collovald \& Neveu 2004), taking into account the economic and symbolic capital of publishers and collections. They are also based on Anita Torres' updated work (Torres 1997). Those who only publish "pure" (i.e. scientific) science fiction are also indicated, as well as those 
dedicated solely to fantasy, as most publishers publish both (for more details, see Hommel 2017: 55-75).

10. Because of the imaginary nature of the genre, readers are overexposed to the suspicion of not being able to distinguish fact from fiction, or of trying to escape reality.

11. Chick-lit is a pejorative way of referring to a usually sentimental novel production, destined for young women. It can include realist novels as well as speculative fiction.

12. Although some interviewees display practices perceived as less legitimate (collection, cosplay), they co-exist in our sample with reading modes that imply a certain reflexivity (resources to analyse the world around them, help in the construction of self, amongst other ethical-practical uses), even in the absence of actual "erudite" reading.

13. A BTS (Brevet de technicien supérieur) is a higher education diploma that is taken over two years after secondary school.

14. A study I carried out of social exchanges between readers of speculative fiction (Hommel 2017: 315-346) showed that this readership is particularly prone to discussion in amateur groups, including online, but also with non-readers of the said genre. These talks contribute to forming a critical approach to the read books but also to transmitting "good taste" norms on the matter. The most assiduous readers generally figure as "experts", giving reading tips and critical opinions during these exchanges.

15. Although published in 1954-1955, The Lord of the Rings features passages in old English, used to transcribe the language of the fictional kingdom of Rohan.

16. The books published by Milady condense many of these prejudices, especially those associated with bit-lit (sentimental literature featuring vampires and werewolves).

17. Complementary work to The Lord of the Rings and The Hobbit, which retraces the whole genealogy and mythology of Middle-earth.

18. A DUT (Diplôme universitaire de technologie) is a higher education diploma from a technological university, equivalent to two years of post-secondary school studies.

19. A DEUG (Diplôme d'études universitaires générales) is a general studies diploma, equivalent to two years of post-secondary school studies.

20. The «bac» (baccalauréat) is a French exam and diploma obtained at the end of the secondary cycle.

21. Mainly crime novels for Marc's mother, "all of Stephen King" and "contemporary novels" for Benjamin's mother, who has a subscription to France Loisirs, a popular bookselling club.

\section{ABSTRACTS}

The legitimacy of speculative fiction - a broad fiction category that includes science fiction and fantasy - varies according to the choice of texts. This article analyses what is at stake when reading literary genres with ambiguous legitimacy, by describing how this supposed illegitimate reading can be transformed into a social and cultural resource. After discussing the prejudices that science fiction and fantasy readers face, it shows how the genre's internal legitimacy hierarchy allows for strategies of distinction amongst, not only individuals with a strong cultural capital, but others as well, through their choice of books and adopted reading methods.

Les littératures de l'imaginaire, catégorie éditoriale qui regroupe science-fiction et fantasy, présentent des niveaux de légitimité variables selon les titres. Cet article propose une analyse des 
enjeux lectoraux liés à la légitimité ambiguë de ces productions chez les lecteurs et lectrices, en décrivant comment cette lecture soupçonnée d'illégitimité peut se transformer en une ressource sociale et culturelle. Après avoir évoqué les jugements auxquels font face les lecteurs et lectrices de science-fiction et fantasy, il montre comment la hiérarchie de légitimité interne au genre rend possible la mise en place de stratégies de distinction chez les individus à fort capital culturel, mais pas uniquement, à travers le choix des titres lus et les modes de lecture adoptés.

\section{AUTHORS}

\section{ÉLODIE HOMMEL}

Université Paul Valéry (Montpellier 3)/Centre Max Weber 